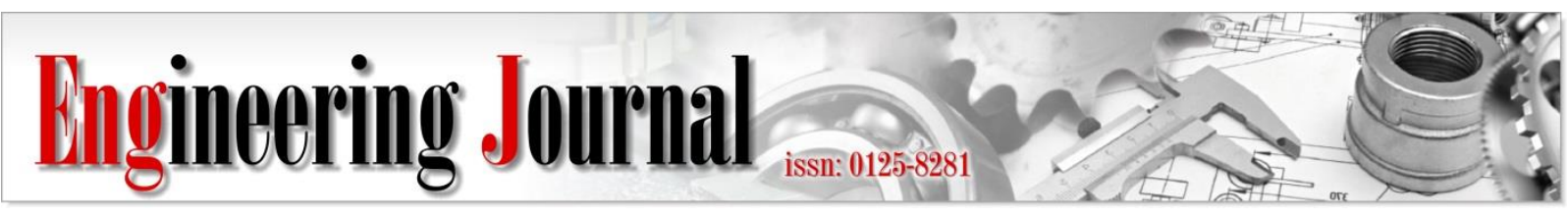

Article

\title{
Forecasting Annual Solar PV Capacity Installation in Thailand Residential Sector: A User Segmentation Approach
}

\author{
Muhammad Fachrizal ${ }^{1, a}$ and Jing Tang ${ }^{1,2, b, *}$ \\ 1 Sirindhorn International Institute of Technology, Thammasat University, Pathum Thani 12120, Thailand \\ 2 International School of Engineering, Faculty of Engineering, Chulalongkorn University, Bangkok 10330, \\ Thailand \\ E-mail: afachrizal.muhammad@gmail.com, bjing.t@chula.ac.th (Corresponding author)
}

\begin{abstract}
Solar PV is one of the fast-growing renewable energy in Thailand. Three sectors are contributing to solar PV installation, which are solar farms, industrial, and residential sector. However, the latter only contributes $1.39 \%$ of the cumulative capacity in 2016 . By considering the lowering price of installation cost, growing affordable households, and a vast amount of solar irradiation in Thailand, it is of interest to observe the potential of the residential sector. Besides, there is a lack of study that focuses on the forecasting of residential solar PV in Thailand. Thus, this paper emphasizes on annual installation forecast of solar PV capacity in Thailand residential sector by using segmentation. This research categorizes residents into four categories, PV users with and without batteries, potential users, and rejecters, aimed to understand different types of users. An online survey of Thai residents about solar PV utilization was conducted from December 2017 to February 2018 to collect the data for the research. The results find that there is an exponential trend of increasing residential solar PV installation, followed by the reduction of payback period over time. It is forecasted about 3,511.4 MW of residential PV installation in the end of forecasting period. This research helps the decision maker to update the policies.
\end{abstract}

Keywords: Solar photovoltaic (PV), forecasting, residential sector, user segmentation.

ENGINEERING JOURNAL Volume 23 Issue 6

Received 3 April 2019

Accepted 30 September 2019

Published 30 November 2019

Online at http://www.engj.org/

DOI:10.4186/ej.2019.23.6.99 


\section{Introduction}

In the 1970s, the energy crisis, especially petroleum energy, received considerable attention from many countries in the world [1]. Moreover, the Intergovernmental Panel on Climate Change (IPCC) stated that increasing fossil carbon dioxide emissions would cause further global warming over the coming decades [2]. An essential transformation of the energy supply system is needed to accommodate these two problems, e.g., substitution of fossil fuel to renewable energy technologies [3]. Renewable energy technologies have abundant sources and are possibly able to supply the world's energy demand. The sources, such as wind, hydropower, solar, geothermal, ocean, and bioenergy, can supply sustainable energy production [4].

Solar energy is one of the most promising renewable energy sources as it has potential beyond the global energy demand [5]. However, according to the International Energy Agency [6], solar energy contribution to the global energy supply is still insignificant. In 2017, the cumulative solar photovoltaics (PV) capacity of the world reached $402.5 \mathrm{GW}$. The top three countries having the most solar PV capacity installation are China, the United States, and Japan which account for $131 \mathrm{GW}, 51 \mathrm{GW}$, and $49 \mathrm{GW}$, respectively [7]. Besides a relatively unlimited amount of sunshine throughout the year especially in tropical regions, sunshine can be converted into electricity by using solar or PV cell technology without pollution.

With a high amount of solar energy throughout the country, Thailand receives the energy about 1825$1935 \mathrm{kWh} / \mathrm{m}^{2}$ per year. On average, solar energy is $1875 \mathrm{kWh} / \mathrm{m}^{2}$ annually [8]. Months, such as April and May, give the country high solar energy ranged $5.6-6.7 \mathrm{kWh} / \mathrm{m}^{2}$ per day. Besides, the northern and northeastern part of Thailand can be exposed to 6-8 hours daily [9]. Thus, makes Thailand one of the ASEAN countries, which receives the highest possible solar radiation [10]. In the global solar PV share, Thailand is ranked at the $16^{\text {th }}$ by the end of 2017 . The solar photovoltaic (PV) market in Thailand has been leading in ASEAN, with a cumulative capacity of 2,752 MW in 2016. The number is far beyond compared to the second lead, Malaysia, with its cumulative capacity of 250 MW in 2016 [11, 12]. The Energy Policy and Planning Office (EPPO), under the Ministry of Energy of Thailand, issued a renewable energy plan.

The plan, namely the Alternative Energy Development Plan 2015-2036 (AEDP 2015), was aimed to increase renewables in the form of electricity, biofuel, or heat. The renewable energy consumption target was already revised four times by Thai government within eight years span from 2007 to 2015. The target was $30 \%$ of the country's energy consumption by 2036 which made renewable energy as one of Thailand's primary focus [13]. The AEDP 2015 targeted to reach 19,684 MW of electricity generation from renewable energy by 2036, with solar energy was expected to contribute the most with 6,000 MW [12]. Biomass and wind energy, as the second and third most, were being targeted to reach 5,570 MW and 3,003 MW, respectively. Moreover, the International Renewable Energy Agency (IRENA) created a report researched about renewable energy assessment. By using its Renewable Energy Roadmap (REmap) analysis tool, it was aimed to recognize the potential development of current the AEDP 2015 Plan. The result was that Thailand had potential to rise current the AEDP 2015 target from 30\% by 2036 to 37\%. This report predicts the total of capacity contributed from renewable energy could reach 34,000 MW. Solar PV was projected as the largest additional potential, from 6,000 MW in AEDP 2015 to about 17,200 MW at the end of the forecast [14].

There are several factors contributing the rise of solar PV potential in Thailand. Firstly, the amount of installed capacity throughout the country is expected to increase, as the Energy Regulatory Commission (ERC) regulates industrial solar PV usage [15]. Secondly, technology development has significantly reduced solar PV installation cost. Due to the reduced solar PV installation costs, adopting solar PV becomes more convenient for the solar PV market. Three major market segments are composing the solar PV market in Thailand: solar farm, industrial, and residential sector [16]. Despite that, the residential sector is still untouched by the government of Thailand due to the insignificant contribution to the current installed capacity.

Residential sector has $22.91 \%$ of electricity energy consumption in 2013 , with the demand of 37,657 GWh [17]. In 2016, solar rooftop for self-consumption reached $38 \mathrm{MW}$, accounting 1.39\% of cumulative capacity, for both industrial and residential sector [18]. Self-consumption solar PV, as a decentralized model, has strong prospects to develop and need to be expanded to increase domestic energy and self-reliance [19]. Because of the accelerated growth of solar PV capacity has, observing emerging PV users in Thailand is of interest [20]. Evaluating the residential sector individually is needed because it is possibly as future's key contributor to Thailand fast growing in the solar PV market. Moreover, there is no current residential forecast of PV capacity in Thailand. Hence, this paper focuses on residential PV capacity forecast by considering several factors, i.e., income, payback period, household growth, and PV users' segmentation. 
The primary objective of this paper is to contribute to the utilization of solar PV users' segmentation in Thai residents in forecasting solar PV installation in the future. An understanding of the segmentation enables us to be aware how the groups contribute to the model and are differentiated. The paper is started by discussing solar PV in Thailand and segmentation model of PV users. Then, input data explains about the segmentation used in this paper and how the data collected with its forecasting method. Results and discussion are discussed after that. Finally, the conclusion of the paper is discussed.

\section{Fundamentals}

\subsection{Residential Solar PV in Thailand}

Thai residential electricity demand has grown simultaneously for two decades ago. As in 2008, household power demand reached about 28,528.4 GWh which account for eight times rise from 1982 [20]. If Thai government urges to make sure adequate electricity supply to accommodate the growing demand, decentralized model of residential solar PV should be encouraged. Land management and urbanization are one of the contributing factors for solar PV development. According to the United Nations, Thailand had $1.6 \%$ of yearly urbanization growth rate which made solar PV system could deliver key benefit for reducing peak demand from the grid [21]. Besides, government policies and subsidies contribute a significant impact in encouraging solar PV installation growth.

Thai government's policies, supporting solar PV implementation, can be separated by two periods. The first one was the Adder Program to encourage renewable energy generation, especially solar PV installation, by initiating Feed-In Tariffs (FITs). The program was established in 2006, and executed at the beginning of 2007. The primary goal of the program is to add an extra payment to renewable energy producers above the regular prices when they sell their generated electricity to government's power utilities. Thai government legislated a Very Small and Small Power Purchase (VSPP and SPP) Act, enabling small producers to sell their generated electricity to the grid. VSPP is defined as power producer which generates less than or equal to $10 \mathrm{MW}$. While SPP is a power plant which generates no more than $90 \mathrm{MW}$. Both categories include cogeneration and renewable energy. [22]

The second period was in 2010, Thai government changed the FITs scheme from a premium-price FITs payment to a fixed-price FITs payment [15]. This happened as the government updated the solar target plan. According to the Department of Alternative Energy Development and Efficiency (DEDE), they allocated roughly about $f_{9}$ million for solar energy development [23]. The budget focused on solar PV integration, low-cost solar hot water and small-scale cooling systems, and recycling PV panel. In 2016, the solar installed capacity in Thailand was 2,752 MW which accounted for 45.9\% of AEDP 2015 target. FITs rates were accepted by the National Energy Policy Commission (NEPC) for rooftop solar PV, and community ground mounts for 25 years period [9]. In August 2015, the Thai government stopped the support for residential solar PV as the quota was already fulfilled.

\subsection{Market Segmentations of Solar PV Users}

Kotler introduced segmentation as the division of the market into a group of buyers distinguished by needs, characteristics, or behaviors which may require a separate product [25]. In line with Kotler's opinion, Kasali defined segmentation as the process of dividing or grouping consumers into more homogeneous boxes. The existence of more homogeneous boxes indicates that consumers in a group have the same or similar characteristics [26]. Schiffman and Kanuk had a similar view that market segmentation divided the entire market potential into smaller and similar ones to find the needs of more specific consumer groups. Once the needs of the specific consumer group are identified, the promotions and products can be designed. There are many devisable ways in which way a market can be segmented; where consumer's house is located, who is consuming a service or product, why consumers buy the service or product, etc. Nevertheless, the segmentation itself is based on a finite number of characteristics [27].

Peter et al. described segmentation as a market process into groups. Each market group consists of consumers who have in common. The segmentation process is carried out to the stage of determining the most appropriate consumer group to be targeted by the company. In the process of segmentation, analyzing the relationship is an initial stage to relate the consumer and the product, such as; aspects of affection, cognition, behavior, environment which affect the process of using the product [28]. 
User segmentation involves separating user into groups based on predefined characteristics. Data acts as a main role in this segmentation. Segments are constructed by using models which measures how different groups can be taken into and what metric should define those groups. [29]

Vasseur \& Kemp classified PV consumer in the Netherlands into four groups which were PV users (voluntary and involuntary) and non-users (potential users and rejecters) by examining segmentations such as demographic, geographic, psychologic, and behavior [30]. Those segmentations help to build a glimpse of which types of people use or reject a system. The conversion from a group to another group is possible. In another publication [31], they found that electricity bill savings are the essential motive to install a PV system in their houses $(66.7 \%)$. The second most is costs efficient system which is accounted for $50 \%$. For the main barriers for adopting PV system are a high investment and not a homeowner $(58.3 \%$ and $28.8 \%$, respectively). There are some conditions can convert PV non-user to be a PV user. Those are significantly investment drop (47.8\%), maximum five years of payback period $(36.3 \%)$, and a government subsidy $(31.3 \%)$. These show that economic factors affect household decision significantly.

\section{Input Data}

\subsection{Data Collection}

An online survey combined with the interview was conducted from December 2017 to February 2018 for Thai residents mostly living in Bangkok and Metropolitan Area. The survey was spread randomly to 1500 residents to make a diverse range of data on a random basis. The total obtained data were 614 survey responses. Thus, the response rate is $40.9 \%$. The data is restricted residents who earn income more than $\mathrm{B}$ 50,000 monthly. The threshold number is obtained from one of Krung Thai Bank criteria in giving residential solar loan [32]. Any number lower than that considered have a very low probability of purchasing PV system in their houses. So, usable data used for the empirical analysis was 411. A further interview was an optional as the specific respondent was contacted when his given data was missing or unclear.

The survey asked respondents about their basic demographic and geographic information such as full name, city, PV installation status, salary range, and proper payback period for PV system installation. The respondents who have PV system in their houses are asked further detail about the system installation, before-after installation electrical cost, installation, and maintenance cost. The survey was designed to be main sources of initial forecast in this paper. In other words, the data from the survey needs to be processed further to do the forecast. By using such a questionnaire framework, we can find the residential segmentation and can deliver a more realistic particular situation for respondents.

A statistic for the household number in Thailand is also required to do household forecast in the future. The forecast uses regression analysis to predict the household number until 2036 on an annual basis. As percentage ratio will be used in the majority of equations, household number provides the base for the calculation.

\subsection{Segmentation of Solar PV Users in the Thailand Residential Sector}

A segmentation model is introduced to comprehend more detail about resident's perspective toward solar PV installation. To understand types of solar PV installation in resident's houses, a classification is formulated to distinguish solar PV users and non-users. The existence of solar PV installation is being observed whether a resident has a PV system or not in his house. It is positioned in x-axis as installation status. While y-axis is utilized as the attitude of the respondents, it differs into positive and negative attitude.

The residents who have PV system in their houses are categorized as PV users which can install the system with or without batteries. Also, for those who have not installed the system in their houses are separated into two categories: potential users who have a willingness to install the system in the future and non-users who do not have any intention at all. Therefore, a classification for residents is proposed, namely: (1) PV users with batteries, (2) PV users without batteries, (3) potential users, and (4) non-users.

So as comprehend the solar PV meaning for the residents, it is considered to take a glimpse of the solar PV usage. Viewing a solar PV installation in a house is the primary consideration for grouping the collected data. The residents who have installed PV systems in their houses will be grouped in PV users, while the one who has not installed the systems will be classified as non-users. Comprehension of the PV users (with 
and without batteries) and non-users (potential users and rejecters) enable us to know how the groups are distinguished. Figure 1 shows the classified groups.

\begin{tabular}{|c|c|c|c|}
\hline \multirow{4}{*}{ Attitude } & Positive & PV users with batteries & Potential users \\
\hline & Negative & PV users without batteries & Rejecters \\
\hline & & PV users & Non-users \\
\hline & \multicolumn{3}{|c|}{ Installation status } \\
\hline
\end{tabular}

Fig. 1. Residential model for PV users.

In this paper, PV users' attitude and installation status are specified from the questionnaire responses. First, the respondents are asked if they install a PV system in their houses or not. If they have an installed PV system, we asked the types of installation whether it is with or without batteries. If the respondents installed with batteries, they are categorized as having a positive attitude as they have to repurchase the batteries every three years. In contrast, they are categorized as having a negative attitude as they have a system without considering energy losses and fulfill a specific usage of PV on electronic devices or lightning. If they do not have a PV system in their houses, a difference is labeled between respondents who plan to install a system in the future or not. They are labeled respectively as potential users and rejecters. The potential users can convert into PV users in the future as they already have intentions to install the system in their houses. On the contrary, rejecters have no intention at all to purchase the system in their houses.

\subsection{Assumptions}

There are four assumptions used in this paper, as follow: (1) No policy changes for the residential sector. Forecasts for 2018 and beyond reflect a no-policy-change scenario as until now only the industrial sector is being applied for the policies by the government. (2) No significant PV technology development within the forecast period. (3) Power Purchase Agreement (PPA) is not considered because of the relatively small installation capacity in a household. (4) The inflation rate is compensated by using variables such as affordable household's percentage and installation cost growth rate.

\subsection{Forecasting Model}

There are several variables used in this paper. Table 1 shows each variable with its definition and unit. The interrelation between those variables is explained with causal loop diagram (CLD) as seen in Fig. 2. The main variables are payback period, growth rate of solar PV users, and installed capacity.

\subsubsection{Payback period}

Electricity saving is considered as the essential motive in adopting a PV system [31]. The payback period, especially for energy, should always be one of the criteria used for comparing the viability of one renewable technology against another. We define the payback period as the total years needed for electricity saving can reach the break-even point with the investment cost [33]. It is defined without the consideration of the time value of money. The payback period formula is given on Eq. (1) below.

$$
P P_{t}=P P_{t-1} *\left[\frac{\left(1+\% I X_{t}\right)}{\left(1+\% E P_{t}\right)}-1\right]
$$

where $\% I X_{t}$ is installation cost growth rate percentage, and $\% E P_{t}$ is the electricity price growth rate percentage. As the value of payback period changes every year, there will be payback period growth rate to determine predicted payback period for the next year. 
In Fig. 2, payback period variable is affected by the installation cost growth rate and electricity cost growth rate. The higher installation cost growth rate is, the more extended payback period will be. In contrast, the higher electricity cost growth rate is, the shorter payback period will be. When the installed PV system covers the house's electricity demand, the PV users do not need to pay the electricity price monthly.

Table 1. Variables used in the paper.

\begin{tabular}{|c|c|c|c|}
\hline Variables & Symbol & Definition & Unit \\
\hline $\begin{array}{l}\text { Electricity price growth } \\
\text { rate percentage }\end{array}$ & $\% E P_{t}$ & $\begin{array}{l}\text { Percentage of electricity price } \\
\text { growth rate occurred in a year }\end{array}$ & $\%$ \\
\hline $\begin{array}{l}\text { Growth rate of installed } \\
\text { capacity }\end{array}$ & $\frac{d I C_{t}}{d t}$ & $\begin{array}{l}\text { Ratio of installed capacity growth } \\
\text { between two years }\end{array}$ & MW/year \\
\hline $\begin{array}{l}\text { Growth rate of solar PV } \\
\text { users }\end{array}$ & $\% H H G_{t}$ & $\begin{array}{l}\text { Conversion rate from potential } \\
\text { user to be a PV user in year } t\end{array}$ & $\%$ \\
\hline $\begin{array}{l}\text { Affordable household's } \\
\text { percentage }\end{array}$ & $\% A H$ & $\begin{array}{l}\text { Percentage of high-earning } \\
\text { households }\left(>_{B} 50,000 / \text { month }\right)\end{array}$ & $\%$ \\
\hline Household number & $H H_{t}$ & Household number in Thailand & households \\
\hline $\begin{array}{l}\text { Installation cost growth } \\
\text { rate percentage }\end{array}$ & $\% I X_{t}$ & $\begin{array}{l}\text { Cost used to purchase the solar PV } \\
\text { system in year } t\end{array}$ & $\%$ \\
\hline $\begin{array}{l}\text { Installed capacity with } \\
\text { batteries per household }\end{array}$ & $I C_{(w b), t}$ & $\begin{array}{l}\text { Average amount of energy } \\
\text { generated by the PV system with } \\
\text { batteries in year } t\end{array}$ & MW/households \\
\hline $\begin{array}{l}\text { Installed capacity without } \\
\text { batteries per household }\end{array}$ & $I C_{(w o b), t}$ & $\begin{array}{l}\text { Average amount of energy } \\
\text { generated by the PV system } \\
\text { without batteries in year } t\end{array}$ & MW/households \\
\hline $\begin{array}{l}\text { Ratio of users with } \\
\text { batteries }\end{array}$ & $\% I C_{(w b)}$ & $\begin{array}{l}\text { Ratio of users with batteries per } \\
\text { total PV users in questionnaire } \\
(2 / 5=40 \%)\end{array}$ & $\%$ \\
\hline $\begin{array}{l}\text { Ratio of users without } \\
\text { batteries }\end{array}$ & $\% I C_{(w o b)}$ & $\begin{array}{l}\text { Ratio of users without batteries per } \\
\text { total PV users in questionnaire } \\
(3 / 5=60 \%)\end{array}$ & $\%$ \\
\hline Installed capacity & $I C_{t}$ & $\begin{array}{l}\text { Amount of energy generated by } \\
\text { solar PV system in year } t\end{array}$ & MW \\
\hline Payback period & $P P_{t}$ & $\begin{array}{l}\text { Total years needed for saving to be } \\
\text { equal to investment cost }\end{array}$ & year \\
\hline $\begin{array}{l}\text { Percentage of total } \\
\text { projected PV users }\end{array}$ & $\% T U I_{t}$ & $\begin{array}{l}\text { Percentage of total projected PV } \\
\text { users in year } t\end{array}$ & $\%$ \\
\hline $\begin{array}{l}\text { Percentage of total current } \\
\text { PV users }\end{array}$ & $\% C U I_{t}$ & $\begin{array}{l}\text { Percentage of total current PV } \\
\text { users in year } t\end{array}$ & $\%$ \\
\hline
\end{tabular}




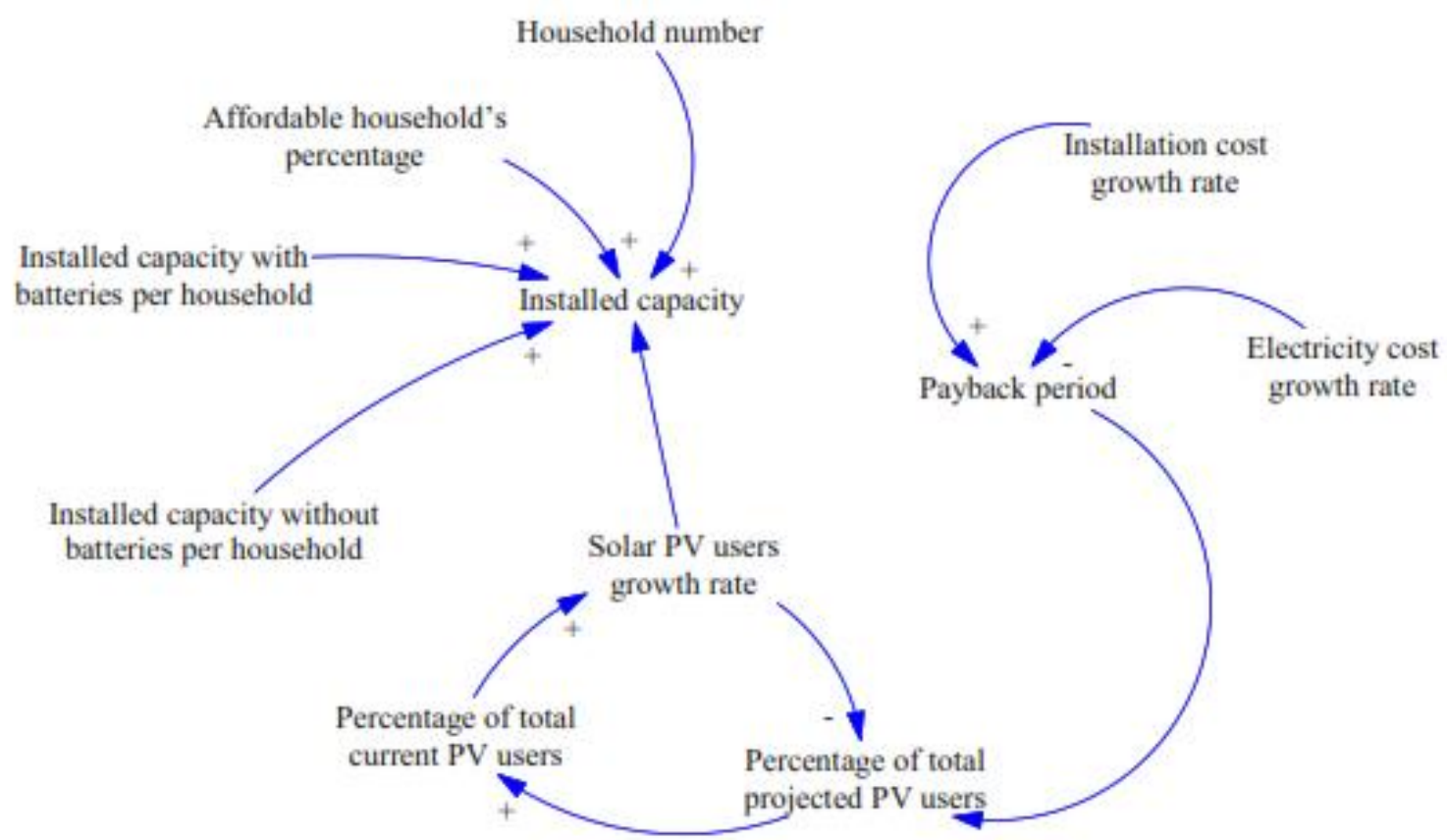

Fig. 2. Model's causal loop diagram (CLD).

\subsubsection{Growth rate of solar PV users}

Potential users who have already intended to be a PV user in the future can increase the current percentage of PV users. The potential users mostly tend to purchase solar PV system in their houses within 15 years as they need some considerations first. The time needed to decide to purchase solar PV system refers to decision lag. Fewer installation means less stimulation for the next installment. However, the more people install solar PV, the more affecting it influence the others to install either. Equation (2) shows the formula on how to calculate the growth rate of solar PV users.

$$
\% H H G_{t}=\frac{\% T U I_{t}-\% C U I_{t}}{15}
$$

where $\% T U I_{t}$ is the percentage of total projected PV users in year $t$, and $\% C U I_{t}$ is the percentage of current PV users in year $t$. Subtraction of $\% T U I_{t}$ by $\% C U I_{t}$ determines the net percentage of potential users throughout the residents. This variable can be considered as conversion from potential users to PV users.

In Fig. 2, the growth rate of solar PV users is influenced by the percentage of total PV users and is affecting installed capacity and percentage of projected PV users. The percentage of total PV user's variable gives support to the growth rate of solar PV users. The more the former, the more the latter. So does the growth rate of solar PV users and installed capacity relationship. In contrast, the more of this variable, the less percentage of projected PV users as the projected PV users (potential users) already converted to PV users.

\subsubsection{Installed capacity}

Installed capacity is the most important variable in this paper. It is forecasted by using previous year's installed capacity, added by a predicted growth rate of PV users multiplied by the ratio of PV user's installation both with and without batteries. The ratio is obtained from the questionnaire responses which the amount of energy generated by the PV system in year $t$ is formulated in Eq. (3) below.

$$
I C_{t}=I C_{t-1}+\left(H H_{t-1} * \% A H * \% H H G_{t-1}\right) *\left(I C_{(w b), t-1} * \% I C_{(w b)}+I C_{(w o b), t-1} * \% I C_{(w o b)}\right)
$$


where $I C_{t-1}$ is last year's predicted installed capacity, $H H_{t-1}$ is last year's household number, $\% H S$ is last year's percentage of residents who earn a monthly salary more than $\mathbb{B} 50,000, I C_{(w b), t-1}$ is last year's installed capacity with batteries per household, $I C_{(w o b), t-1}$ is last year's installed capacity without batteries per household, and $\% H H G_{t-1}$ is last year's growth rate of solar PV users. The $I C_{(w b), t-1}$ and $I C_{(w o b), t-1}$ are affected by the installation cost growth rate as it is, the higher growth rate of these variables are.

In Fig. 2, all of the variables affecting installed capacity contribute supportively. Those variables are household number, affordable household's percentage, installed capacity with batteries per household, installed capacity without batteries per household, and growth rate of solar PV users.

\section{Results and Discussions}

\subsection{User Segmentation}

\subsubsection{Income class}

Income class classifies the ability of residents to purchase the solar PV system in their houses. Residents who earn below than 150,000 per month are considered not able to install the system as they may have other priorities. Income is considered as one of the significant roles to help residents deciding to implement solar PV technology in their houses [34]. In 2017, the National Statistical Office (NSO) held a socioeconomic survey. The combined percentage of households earning a monthly salary more than 1550,000 is $11.1 \%$ for 2017 [35]. Table 2 illustrates the number of PV users and non-users with their income class. From 411 residents, non-users appear as the majority of the group which consists of 362 people $(88.1 \%)$, while PV users with and without batteries are the minority groups accounted for $1.2 \%$ combined (two and three people, respectively). All residents, except PV users without batteries, mostly earn around 850,000 100,000 per month, whereas PV users without battery earn more than $\mathbb{B} 200,000$ monthly as the majority. Non-users with $\mathrm{B} 50,000-100,000$ per month are the biggest category of residents which accounted for 181 people $(29.5 \%)$.

Table 2. Income class of PV users and non-users.

\begin{tabular}{|c|c|c|c|c|c|c|c|c|c|}
\hline \multirow{2}{*}{$\begin{array}{l}\text { Income } \\
\text { (THB/month) }\end{array}$} & \multicolumn{2}{|c|}{$\begin{array}{l}\text { PV users with } \\
\text { batteries }\end{array}$} & \multicolumn{2}{|c|}{$\begin{array}{l}\text { PV users without } \\
\text { batteries }\end{array}$} & \multicolumn{2}{|c|}{ Potential users } & \multicolumn{2}{|c|}{ Rejecters } & \multirow[t]{2}{*}{ Ratio } \\
\hline & $\mathrm{N}$ & $\begin{array}{l}\% \text { in the same } \\
\text { income range }\end{array}$ & $\mathrm{N}$ & $\begin{array}{l}\% \text { in the same } \\
\text { income range }\end{array}$ & $\mathrm{N}$ & $\begin{array}{l}\% \text { in the } \\
\text { same } \\
\text { income range }\end{array}$ & $\mathrm{N}$ & $\begin{array}{l}\% \text { in the same } \\
\text { income range }\end{array}$ & \\
\hline $50,000-100,000$ & 1 & $0.62 \%$ & 1 & $0.62 \%$ & 22 & $3.42 \%$ & 138 & $29.48 \%$ & $162 / 411$ \\
\hline $100,000-150,000$ & 1 & $1.06 \%$ & 0 & $0.00 \%$ & 4 & $1.14 \%$ & 89 & $17.92 \%$ & $94 / 411$ \\
\hline $150,000-200,000$ & 0 & $0.00 \%$ & 0 & $0.00 \%$ & 2 & $0.16 \%$ & 50 & $9.93 \%$ & $52 / 411$ \\
\hline$>200,000$ & 0 & $0.00 \%$ & 2 & $1.94 \%$ & 16 & $1.95 \%$ & 85 & $18.73 \%$ & $103 / 411$ \\
\hline Total & 2 & $0.49 \%$ & 3 & $0.73 \%$ & 44 & $10.71 \%$ & 362 & $88.08 \%$ & $411 / 411$ \\
\hline
\end{tabular}

\subsubsection{Capacity per household}

Based on the questionnaire, we got the data of installed capacity per household for each with batteries and without batteries are $0.33 \mathrm{~kW}$ and $2.07 \mathrm{~kW}$ in 2018 , respectively. As the installation cost growth rate percentage affects the growth rate of installed capacity per household, the latter is used as the growth factor from the previous year's installed capacity. For with batteries group, we use $6.67 \mathrm{~kW}$ as maximum installment. While for without batteries group, we use $2.50 \mathrm{~kW}$. By 2036, $0.83 \mathrm{~kW}$ and $2.50 \mathrm{~kW}$ are obtained for with battery and without battery, respectively. 


\subsection{Household Forecast}

We collected the historical data of the Thai household number from the NSO report about Summary of Survey for Economics and Social for Household 2017 [33]. Due to the need for detailed yearly forecast and data source limitation, an annual forecast is needed to be predicted until 2036. The data source provided the actual household number in Thailand from 2012 to 2017. Based on the source, linear regression is needed to find the regression equation $Y=a+b X$ with the higher proportion of variation $\left(R^{2}\right)$ is, the more fit variability in $Y$ is described by the regression equation [34]. The number of $R^{2}$ is 0.9374 , which represents enough from the historical data. Afterward, by using the equation, the household number from 2018 to 2036 is being predicted. Figure 3 shows the number of households in Thailand forecast data. The forecasted value is approximately 28.02 million of Thai household number in 2036, increasing $55.2 \%$ of the Thai households' number in 2018.

The affordable households' data from 2009 to 2017 is obtained from the NSO. The initial share was $7.10 \%$ of the household number (roughly 1.39 million households) in 2009. In 2017, the actual percentage of affordable households was $11.10 \%$ (about 2.42 million households). The forecast for this variable starts from 2018 to 2036, resulting in the total affordable households is $22.82 \%$ (6.39 million households) in 2036.

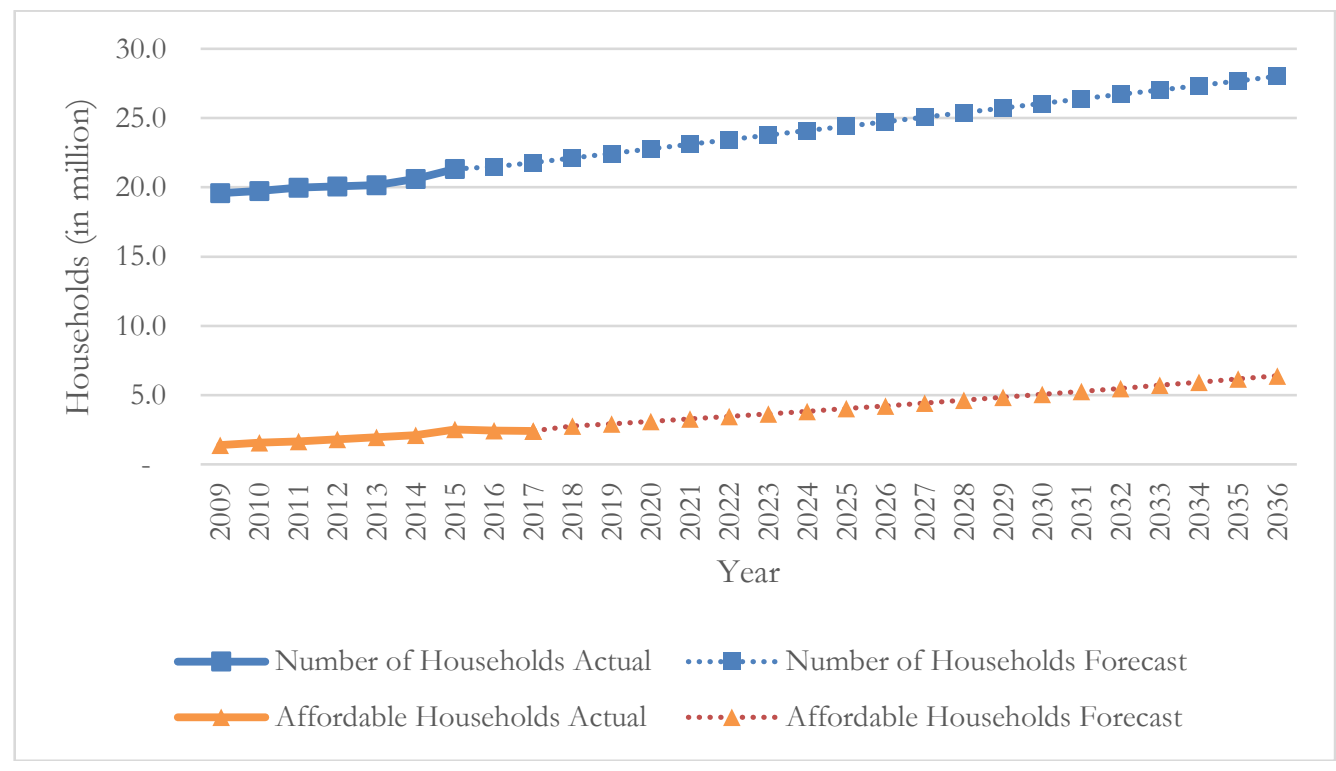

Fig. 3. Thailand's number of households and affordable households - data and forecast.

\subsection{Payback Period - Initial Value and Forecast}

From 411 data, about 354 respondents filled the perceived payback period and resulted in an average of 4.9 years. However, the average perceived payback period may not be accurate in determining the payback period used in the calculation. The perceived payback periods range from 1 to 20 years. The initial value of the payback period is given by creating a cumulative perceived payback period based on the questionnaire. Perceived payback period from the questionnaire, then, is cumulated. For instance, the respondent who picks up the payback period for seven years means willing to install if the payback period below than seven years ( $<7$ years). So, the payback period for 1-7 years will get a percentage share in the chart. After that, the cumulated graph is looked for its regression equation by choosing the highest amount of $R^{2}$. The exponential trendline is the best approach in determining the equation as shown in Fig. 4. As the data collected in 2018, the initial payback period for 2018 is 9.71 years with the exponential regression equation Cumulative percentage of household installing $P V=1.1453 * e^{-0.233 * \text { Perceived payback period }}$ and $R^{2}=0.9486$ which represents well from the historical data. 


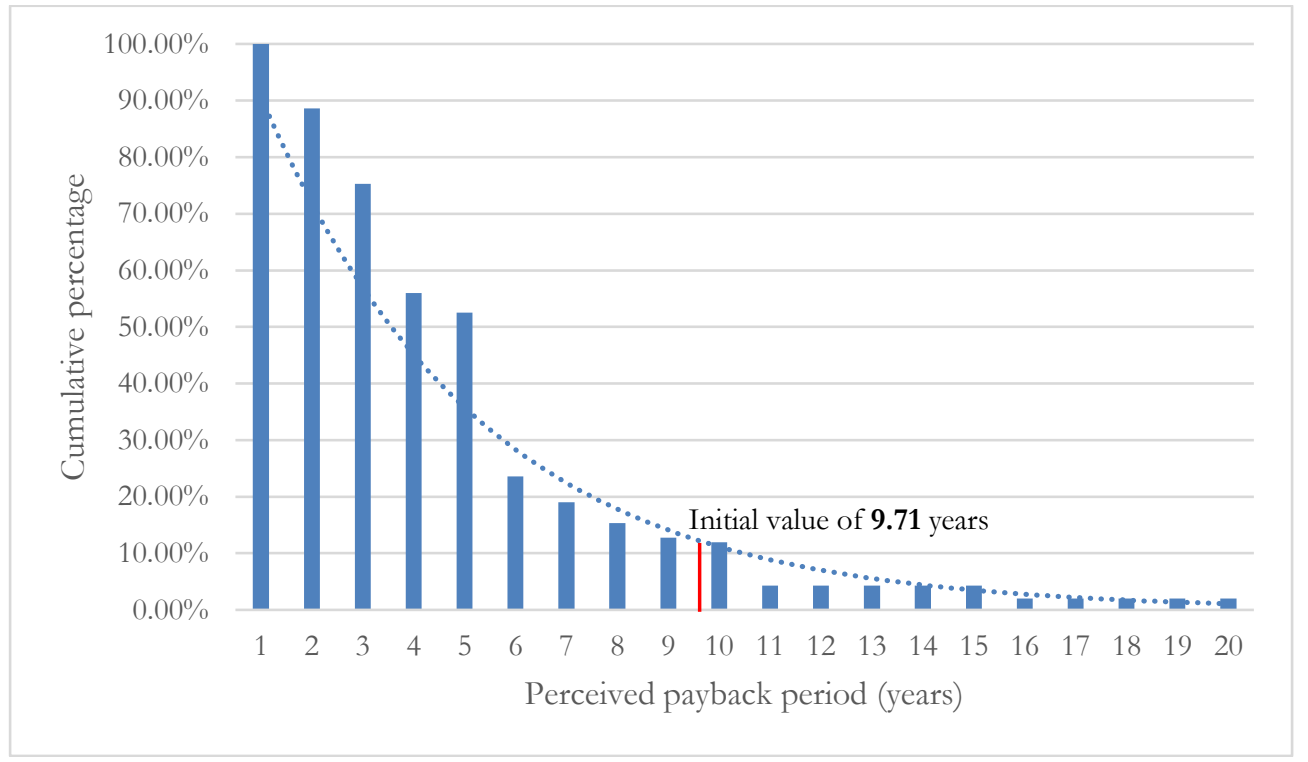

Fig. 4. Perceived payback period based on questionnaire.

As the value of payback period changes every year, there will be payback period growth rate to determine predicted payback period for the next year. A report from the IRENA shows that the average solar PV total installation cost reduces roughly about 5\% annually from 2016 to 2025 [37].

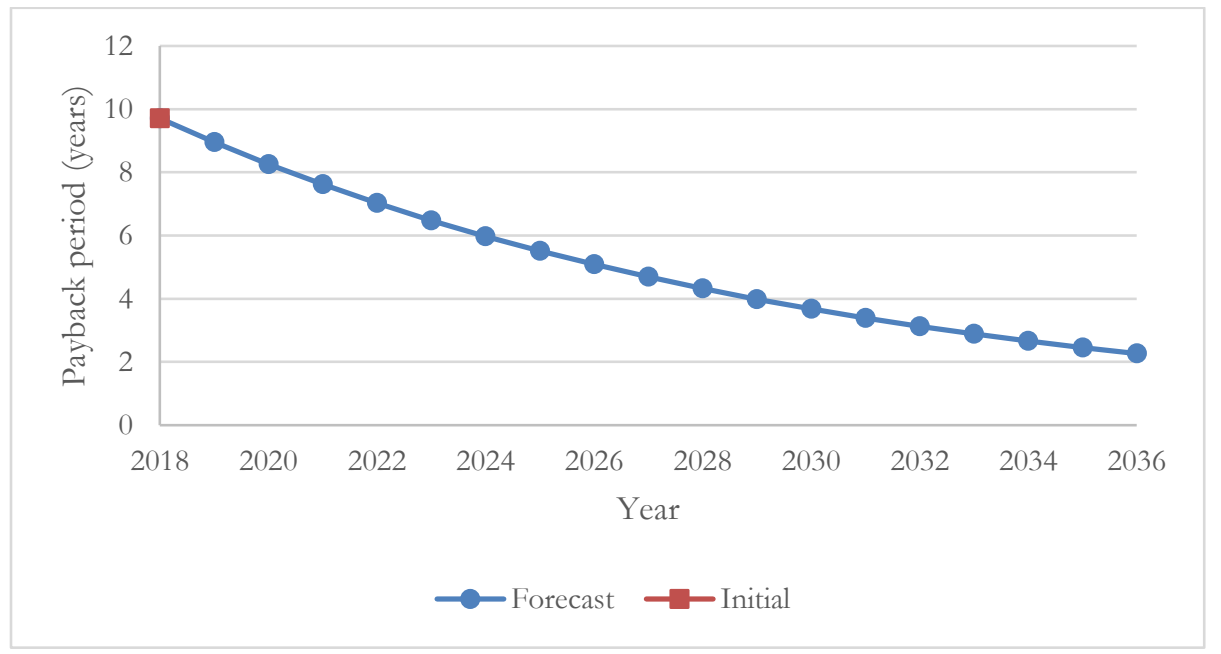

Fig. 5. Payback period forecast from 2019-2036.

\subsection{Forecast of Residential Solar PV Capacity Installation}

Figure 6 shows the annual total capacity of residential PV installation from 2018 to 2036. By the end of 2018, the total capacity is expected equal to $41.6 \mathrm{MW}$. The chart growth exponentially results in the total residential capacity in 2036 roughly about 3,511.4 MW which accounts for $20.7 \%$ of the 17,200 MW IRENA's REmap. The trendline is exponential as the more installation, the more other installations are stimulated, with the exponential regression equation $59.615 * e^{0.2824 * \text { year }}$ and $R^{2}=0.972$. 


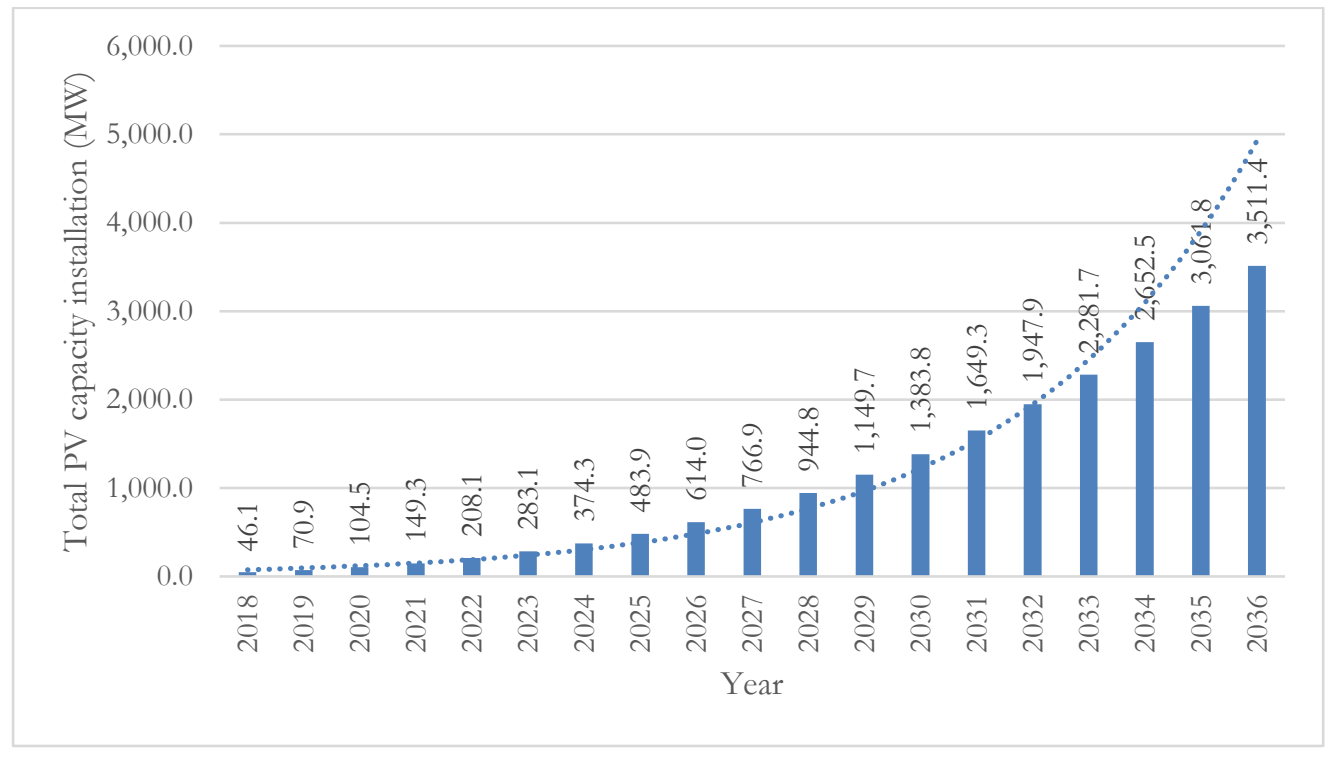

Fig. 6. Forecasted annual total installed capacity in MW.

\subsection{Scenarios}

To forecast the installed, two variables combination is used. The variables to be varied are the installation cost growth rate percentage $\left(\% I X_{t}\right)$, and the electricity price growth rate percentage $\left(\% E P_{t}\right)$. As the values of the two variables are relatively changing, scenarios are needed to observe the influence of those variables. Currently, the data of those variables in Thailand is limited, so using several sources to obtain the values is preferable. Both of these variables affect the payback period.

A decreasing trend of average total installation cost includes the decrease of sub-installation parts [29]. The installation cost consists of PV module price and a balance of system price. This latter includes nonmodule costs such as an inverter, wiring, racking, and labor [38]. Starting in 2015, the constant reduction pattern emerged as an annual decrease is roughly about $5 \%$. Moreover, the government policy, such as Adder Program, stimulates the increasing demand in the country [39]. The advancement of solar PV technology collaborating with the decreasing cost encourages the conversion from potential users to PV users [40]. A report from the IRENA shows that the average solar PV total installation cost reduces roughly about 5\% annually from 2016 to 2025 [37]. The report is also supported by the Solar Energy Industries Association (SEIA) in its report stating that roughly 5\% of solar PV installation reduced from 2014 to 20188 [41]. While another report from the National Renewable Energy Laboratory (NREL) mentioned about 7\% reduction of the installation cost annually [42]. The growth of $0 \%$ will be used as a benchmark value.

In Thailand, the electricity demand is forecasted to increase by about $5.72 \%$ annually between 2007 and 2021 [41]. Thus, the residential electricity price trend is increasing by roughly about 3\% annually from 2014 to 2021 [43]. This value will be used in this scenario. The growth of $0 \%$ for this value also will be used as a benchmark value. Table 3 shows the scenarios used in this paper.

Table 3. Scenarios for forecast.

\begin{tabular}{|c|c|c|c|}
\hline \multirow{2}{*}{$\% E P_{t}$} & \multicolumn{3}{|c|}{$\% I X_{t}$} \\
\cline { 2 - 4 } & $0 \%$ & $-5 \%$ & $-7 \%$ \\
\hline \multirow{2}{*}{$0 \%$} & Scenario & Scenario & Scenario \\
& $0 \%, 0 \%$ & $-5 \%, 0 \%$ & $-7 \%, 0 \%$ \\
\hline \multirow{2}{*}{$3 \%$} & Scenario & Scenario & Scenario \\
& $0 \%, 3 \%$ & $-5 \%, 3 \%$ & $-7 \%, 3 \%$ \\
\hline
\end{tabular}




\subsubsection{Sensitivity analysis}

In the scenario, $\% I X_{t}$ and $\% E P_{t}$ are being varied. For each of the factors, $\pm 1 \%$ variation is used. Figure 7 shows the result of sensitivity analysis for the payback period. Starting at 9.71 years in 2018 for each category, the scenario with a lower value of $\% I X_{t}$ and higher value of $\% E P_{t}$ achieves the faster payback period, which is scenario $-1 \%, 0 \%$ and scenario $0 \%, 1 \%$ with the same results in 2036 . In contrast, scenario $1 \%, 0 \%$ and $0,-1 \%$ affect the longer payback period with the same value in 2036 .

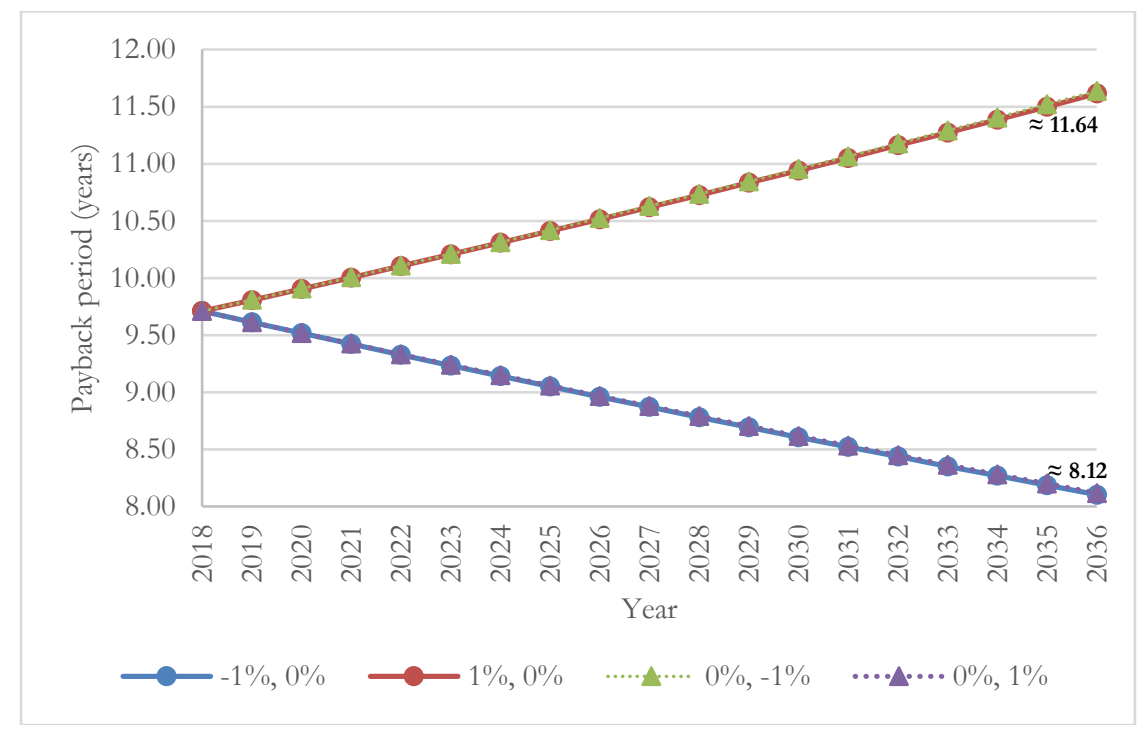

Fig. 7. Sensitivity analysis for payback period.

Figure 8 shows the result of sensitivity analysis for installed capacity. Starting at $46.1 \mathrm{MW}$ in 2018 for each category, the scenario with the lower value of $\% I X_{t}$ and higher value of $\% E P_{t}$ achieves the highest result, which is scenario $-1 \%, 0 \%$. In contrast, scenario $1 \%, 0 \%$ results in the lowest installed capacity in the forecast with the almost similar result with scenario $0 \%,-1 \%$.

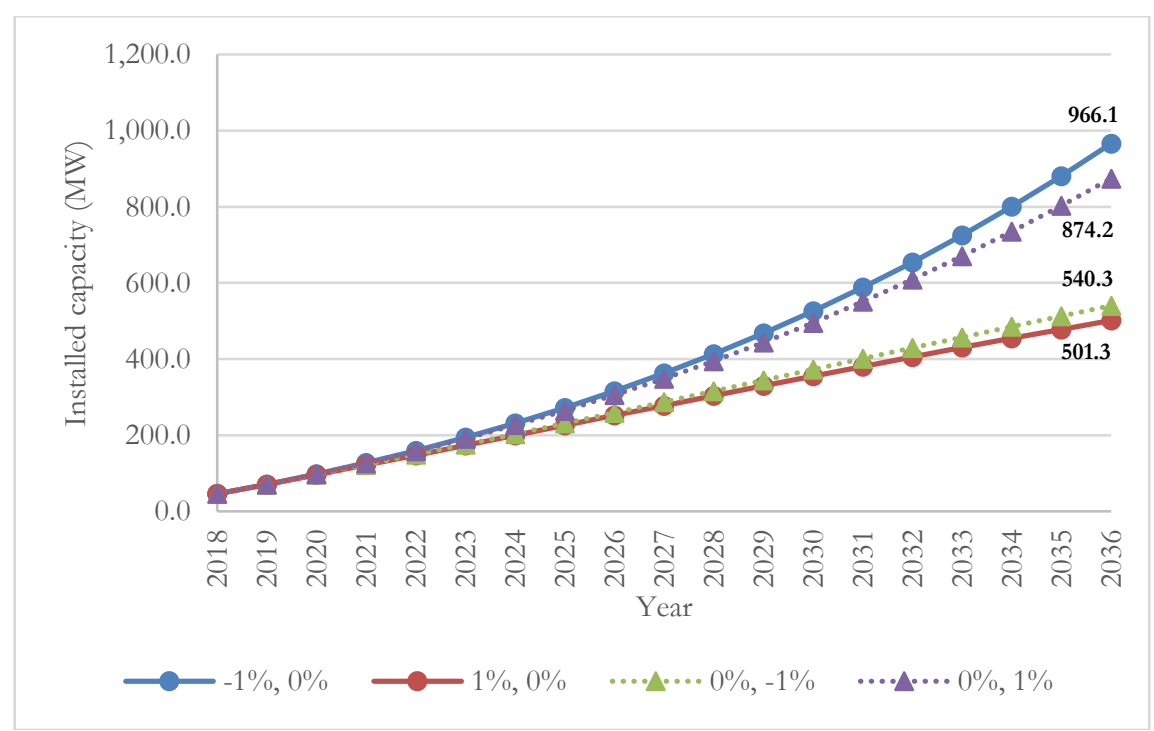

Fig. 8. Sensitivity analysis for installed capacity. 


\subsubsection{Payback period - Scenario}

In Fig. 9, the trend of payback period is reducing exponentially for each scenario based on the forecast. Only $0 \%, 0 \%$ scenario has no payback period change as we assumed no change for both variables, resulting in constant value until 2036. The shortest payback period year is obtained in $-7 \%, 3 \%$ scenario (1.54 years), as the lower installation cost required and the higher electricity savings through years ahead. By comparing the same $\% I X_{t}$ with different $\% E P_{t}$, the result shows the higher $\% E P_{t}$ value will make the payback period shorter. For instance, as seen in the value of $-5 \%, 0 \%$ scenario in 2036 (5.70 years) is more than twice of $5 \%, 3 \%$ scenario $\left(2.27\right.$ years). Moreover, by comparing the constant $\% E P_{t}$ with different $\% I X_{t}$, the result proves that the lower $\% I X_{t}$ resulting in the shorter payback period. For instance, as seen in the value of $5 \%, 3 \%$ scenario in 2036 (2.27 years) is almost more than $50 \%$ of $-7 \%, 3 \%$ scenario (1.54 years).

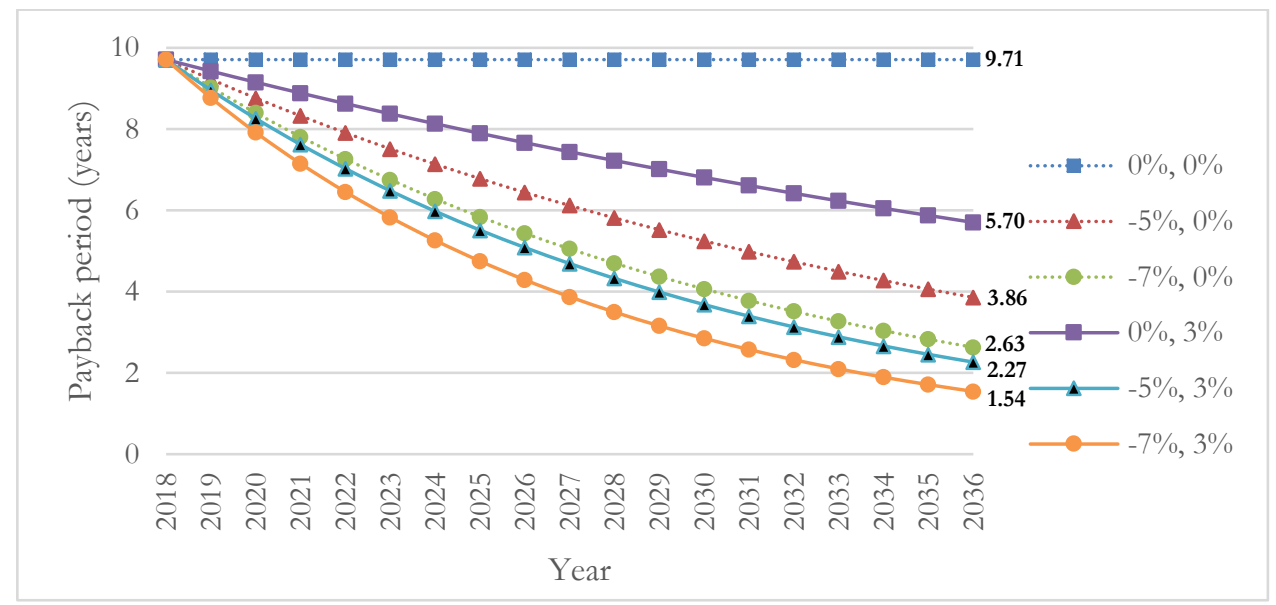

Fig. 9. Forecasted payback period based on scenarios.

\subsubsection{Capacity per household - Scenario}

Based on the questionnaire, we got the data of installed capacity per household for each with batteries and without batteries are $0.33 \mathrm{~kW}$ and $2.07 \mathrm{~kW}$ in 2018 , respectively. As the installation cost growth rate percentage affects the growth rate of installed capacity per household, the latter is used as the growth factor from the previous year's installed capacity. For with batteries group, we use $6.67 \mathrm{~kW}$ as maximum installment. While for without batteries group, we use $2.50 \mathrm{~kW}$. Table 4 shows the forecast of capacity per household in 2036.

Table 4. Forecast of capacity per household - with and without batteries.

\begin{tabular}{lrllll}
\hline Scenario & $\frac{d I C_{t}}{d t}$ & $\begin{array}{l}I C_{(w b), 2018} \\
(\mathrm{~kW})\end{array}$ & $\begin{array}{l}I C_{(w o b), 2018} \\
(\mathrm{~kW})\end{array}$ & $\begin{array}{l}I C_{(w b), 2036} \\
(\mathrm{~kW})\end{array}$ & $\begin{array}{l}I C_{(w o b), 2036} \\
(\mathrm{~kW})\end{array}$ \\
\hline $0 \%, 0 \%$ & $0.00 \%$ & & & 0.33 & 2.07 \\
$-5 \%, 0 \%$ & $5.26 \%$ & & & 0.83 & 2.50 \\
$-7 \%, 0 \%$ & $7.53 \%$ & Initial & Initial & 1.22 & 2.50 \\
$0 \%, 3 \%$ & $0.00 \%$ & 0.33 & 2.07 & 0.33 & 2.07 \\
$-5 \%, 3 \%$ & $5.26 \%$ & & & 0.83 & 2.50 \\
$-7 \%, 3 \%$ & $7.53 \%$ & & & 1.22 & 2.50 \\
\hline
\end{tabular}

\subsubsection{Residential solar PV CAPACITY installation - Scenario}

Figure 10 shows the annual total capacity of residential PV installation from 2018 to 2036 based on scenarios. By the end of 2018, all of each scenario's initial total installed capacity is expected equal to 46 MW in 2018. The total installed capacity for Thai residential sector in 2036 varying based on the scenarios. 
The trendline is exponential as the more installation, the more other installations are stimulated. Relating to the payback period, the shorter payback period encourages the better total installed capacity forecast. As seen in Fig. 6, the highest value from the forecast is in the scenario $-7 \%, 3 \%$ which reaches $4,481 \mathrm{MW}$ by the end of 2036 with 1.54 years of the payback period. The lowest one happens when scenario $0 \%, 0 \%$ is used, resulting in $692 \mathrm{MW}$ with 9.71 years of the payback period. Scenario $-5 \%, 3 \%$ and scenario $-7 \%, 0 \%$ have similar results, accounting for 3,511 MW and 3,345 MW in 2036, respectively. While scenario $-5 \%, 0 \%$ and scenario $0 \%, 3 \%$ have a big gap, accounting for 2,402 MW and 1,319 MW in 2036, respectively.

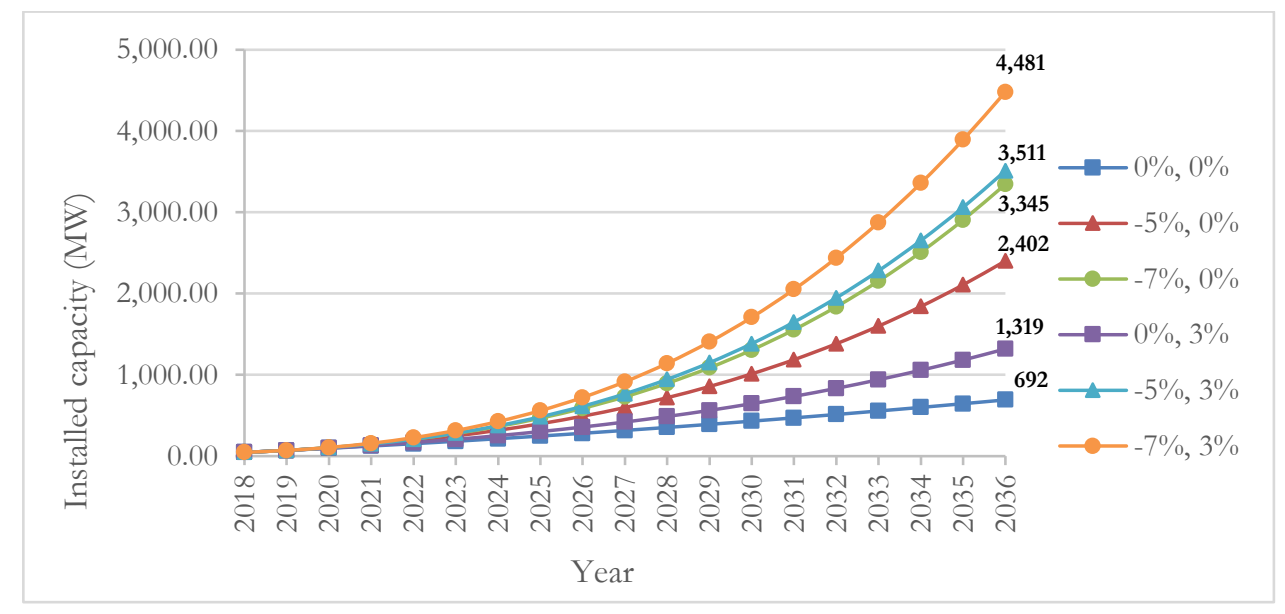

Fig. 10. Forecasted total installed capacity based on scenarios.

By observing the ratio of forecasted total installed capacity to government target, the percentage of residential solar PV contribution is determined. Figure 11 illustrates the percentage share of total capacity and its SPP equivalent in 2036 for each target, based on scenarios. Scenario $-7 \%, 3 \%$ results in the highest value, accounted for fulfilling $26.4 \%$ of IRENA's REmap, and equals to almost 50 SPP. The lowest one happens when scenario $0 \%, 0 \%$ is used, resulting in $4.1 \%$ achievement of the target, and about 8 SPP. Scenario $-5 \%, 3 \%$ and scenario $-7 \%, 0 \%$ have almost identical results, accounting for $20.7 \%$ (39.0 SPP) and $19.7 \%$ (37.2 SPP) in 2036, respectively. While scenario $-5 \%, 0 \%$ and scenario $0 \%, 3 \%$ have a big gap, accounting for $14.1 \%$ (26.7 SPP) and $7.8 \%$ (14.7 SPP) in 2036, respectively.

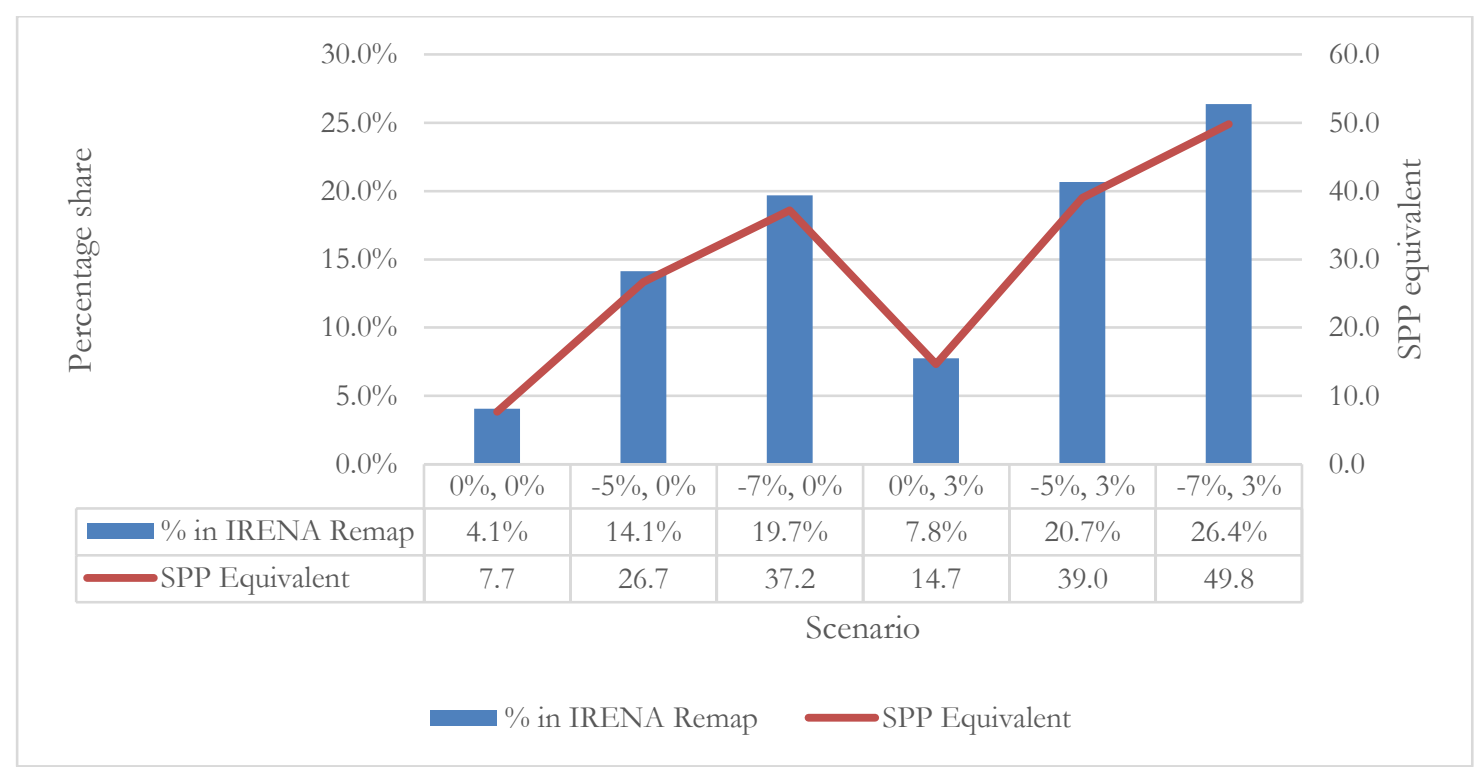

Fig. 11. Percentage share of forecasted value and its SPP equivalent in 2036 for each target based on scenarios. 


\section{Conclusions}

This paper has forecasted the Thai residential installed capacity from 2018 to 2036. The online questionnaire is utilized to collect the data from Thai affordable households. The total usable responses are 411. Respondents are separated into four categories: PV users (with and without batteries), potential users, and rejecters. This indicates that different groups have their own characteristic in determining whether or not to adopt solar PV technology. The forecast considers the ratio of PV users with and without batteries, household number, the percentage of affordable households, payback period, and solar PV installation cost. Several variables are assumed constant such as no policy change, ratio, and no PV technology breakthrough.

By using user segmentation, we observed the conversion of potential users to be PV users in the forecast. At first, there are slow early adopters following the trend. As the trend of installing a PV system is getting more users, the more Thai residents install the system. PV users with and without batteries should be separated as their goal of installing a PV system in their houses is different.

The results in this paper are mainly about payback period and total capacity. The initial payback period in 2018 is 9.71 years, and it is significantly reduced to 2.27 years in 2036. In 2018, the total capacity is roughly about $41.6 \mathrm{MW}$. The forecast results in the total residential capacity in 2036 approximately 3,511.4 MW (20.7\% of the 17,200 MW IRENA's REmap). The trendline is exponential as the more installation, the more other installations are stimulated.

This research, also, uses scenario by varying annual installation cost growth rate and annual electricity cost growth rate. It is found that the trend of payback period will decrease exponentially. As the payback period decreases, the total installed capacity is expected to increase as people are encouraged to install a PV system. The less installation cost growth rate is, the more total installed capacity is. Reversely, the more electricity cost growth rate is, the more total installed capacity is, as electricity saving will be increased on yearly basis.

This paper is one of the initial studies to present evidence for the solar PV forecast in Thai residential sector. These findings indicate that the residential sector plays a significant role in contributing solar PV capacity in the future. The current position accounts for $1.3 \%$ of total solar PV-generated capacity in Thailand. However, there is a possibility in the future that the Thai government establishes a new policy which can affect the growth rate of installation. Such findings enrich the comprehension of the PV market in a country's residential sector. It will be more interesting to complement the analysis by considering the resident's awareness and knowledge about renewable energy.

The findings of this paper offer some suggestions for the Thai government to establish residential PV users' policy, specifically. Fostering a PV installation rate throughout the country (e.g., by giving subsidies and incentives) can increase this technology adoption which means can help to reach AEDP 2015 target for solar PV energy. Policies promoting the adoption of solar PV for industry and resident lead to fruitful meanings of promoting renewable energy technology.

\section{Limitations}

In this paper, there are two main limitations. Firstly, since this study is just a preliminary study in Thailand with 411 samples, it is too early to draw a brief conclusion to predict accurately the residential solar PV capacity. More works in the future need to be done to investigate other nations which might have different culture and perspective. Secondly, most of the respondents are not familiar with the solar PV system. More studies of other variables are needed to increase the accuracy of the proposed model.

\section{Acknowledgement}

The authors would like to express gratitude to the Electricity Generating Authority of Thailand (EGAT) for providing some of the funding in this research. This research is supported by School of Management Technology, Sirindhorn International Institute of Technology, Thammasat University. 


\section{References}

[1] R. Barsky and L. Killian, "Oil and the macroeconomy since the 1970s," Journal of Economic Perspectives, vol. 18, no. 4, pp. 115-134, 2004.

[2] Intergovernmental Panel on Climate Change, Climate Change 2007: The Physical Science Basis. Geneva: IPCC, 2007.

[3] Intergovernmental Panel on Climate Change, Climate Change 2014: Mitigation of Climate Change. New York: Cambridge University Press, 2014.

[4] A. Herzog, T. Lipman, and D. Kammen, "Renewable Energy Sources," in Encyclopedia of Life Support Systems (EOLSS). Berkeley, 2001.

[5] K. Kurokawa, Energy from the Desert: Feasibility of Very Large Scale Power Generation (VLS-PV) Systems. London: Routledge, 2012, p. 1.

[6] International Energy Agency, Energy Statistics of Non-OECD Countries. Organization for Economic Cooperation and Development (OECD), 2012.

[7] International Energy Agency, "Snapshot of global photovoltaic markets," International Energy Agency, Fribourg, 2018.

[8] Reegle, "Energy Profile Thailand," REEEP \& REN21, [Online]. Available: http://www.reegle.info/countries/thailand-energy-profile/TH. [Accessed 24 August 2018].

[9] A. M. Ismail, R. Ramirez-Iniguez, M. Asif, A. B. Munir and F. Muhammad-Sukki, "Progress of solar photovoltaic in ASEAN countries: A review," Renewable and Sustainable Energy Reviews, vol. 48, p. 399412, 2015.

[10] N. Lidula, N. Mithulananthan, W. Ongsakul, C. Widjaya, and R. Henson, "ASEAN towards clean and sustainable energy: Potentials, utilization and barriers," Renewable Energy, vol. 32, no. 9, pp. 1441-1452, 2007.

[11] S. Shan and K. Shan, "Renewable energy guideline on solar photovoltaic (large) project development in Malaysia," Deutsche Gesellschaft für Internationale Zusammenarbeit (GIZ) GmbH, Kuala Lumpur, 2016.

[12] Ministry of Energy of Thailand, “Alternative energy development plan: AEDP2015," Department of Renewable Energy Development and Energy Efficiency, 2015.

[13] T. Sutabutr, "Energy Policy and Planning Office: Annual Report 2015," Energy Policy and Planning Office, Bangkok, 2016.

[14] International Renewable Energy Agency, "Renewable energy outlook: Thailand," International Renewable Energy Agency, Abu Dhabi, 2017.

[15] S. Tongsopit and C. Greacen, "An assessment of Thailand's feed-in tariff program," Renewable Energy, vol. 60, pp. 439-445, 2013.

[16] P. Sathienyanon, “Alternative Energy Development Plan 2015-2036 under Power Development Plan 2015-2036 (PDP2015)," in Thai-German Technology Conference "Biogas in Thailand", Bangkok, 2015.

[17] P. Peerapong and B. Limmeechokchai, "Waste to electricity generation in Thailand: Technology, policy, generation cost, and incentives of investment," Engineering Journal, vol. 20, no. 4, pp. 171-177, 2016.

[18] Federal Ministry for Economic Affairs and Energy, "Thailand Solar PV Policy Update 01/2017," Deutsche Gesellschaft für Internationale Zusammenarbeit (GIZ) GmbH, Berlin, 2017.

[19] T. Sutabutr and W. Chantanakome, "Thailand's Renewable Energy and its Energy Future," Ministry of Energy, Thailand, Bangkok, 2009.

[20] A. Chaianong and C. Pharino, "Outlook and challenges for promoting solar photovoltaic rooftops," Renewable and Sustainable Energy Reviews, vol. 48, pp. 356-372, 2015.

[21] Thailand Energy Situation, "Department of Alternative Energy Development and Efficiency (DEDE)," Ministry of Energy, Bangkok, 2003.

[22] United Nations, "World urbanization prospects The 2011 Revision," Department of Economic and Social Affairs, New York, 2011.

[23] P. Sripattananon, "Renewable project connect experience in Thailand," Provincial Electricity Authority, Bangkok, 2015.

[24] T. Sutabutr, "Renewable energy R\&D trends in Thailand," Department of Alternative Energy Development and Efficiency (DEDE), Beijing, 2012.

[25] P. Kotler, Marketing Management: Analysis, Planning, Implementation, and Control, 9th ed. New Jersey: Prentice Hall, 1999. 
[26] R. Kasali, Membidik Pasar Indonesia: Segmentasi, Targeting, dan Positioning. Jakarta: PT. Gramedia Pustaka Utama, 1998.

[27] L. G. Schiffman and L. L. Kanuk, Consumer Behavior Global Edition, 10th ed., New Jersey: Prentice Hall, 2010.

[28] J. P. Peter, J. Olson, and K. Grunert, Consumer Behavior and Marketing Strategy, 9th ed. Colombus: Mcgraw Hill Higher Education, 2010.

[29] V. Vasseur and R. Kemp, "A segmentation analysis: the case of photovoltaic in the Netherlands," Energy Efficiency, vol. 8, no. 6, pp. 1105-1123, 2015.

[30] V. Vasseur and R. Kemp, "The adoption of PV in the Netherlands: A statistical analysis of adoption factors," Renewable and Sustainable Energy Reviews, vol. 41, pp. 483-494, 2015.

[31] S. Tongsopit, S. Moungchareon, A. Aksornkij, and T. Potisat, "Business models and financing options for a rapid scale-up of rooftop solar power systems in Thailand," Energy Policy, vol. 95, pp. 447-457, 2016.

[32] M. Hosenuzzaman, N. A. Rahim, J. Selvaraj, and M. Hasanuzzaman, "Global prospects, progress, policies, and environmental impact of solar," Renewable and Sustainable Energy Reviews, vol. 41, p. 284 297, 2015.

[33] X. Yuan, J. Zuo, and C. Ma, "Social acceptance of solar energy technologies in China—End users' perspective," Energy Policy, vol. 39, pp. 1031-1036, 2011.

[34] National Statistical Office, "Summary of survey for economics and social for household 2017," National Statistical Office, Bangkok, 2017.

[35] D. C. Montgomery, E. A. Peck, and G. G. Vining, Introduction to Linear Regression Analysis. New Jersey: John Wiley \& Sons, 2012, vol. 821.

[36] International Renewable Energy Agency, "The power to change: Solar and wind cost reduction potential to 2025," International Renewable Energy Agency, Abu Dhabi, 2016.

[37] S. Reichelstein and M. Yorston, "The prospects for cost competitive solar PV power," Energy Policy, vol. 55, pp. 117-127, 2013.

[38] G. Barbose, N. Darghouth, S. Weaver, and R. Wiser, "Tracking the sun VI: A historical summary of the installed price of photovoltaics in the United States from 1998 to 2012," Lawrence Berkeley National Lab. (LBNL), Berkeley, CA, 2013.

[39] G. Kumbaroglu, R. Madlener, and M. Demire, "A real options evaluation model for the diffusion prospects of new renewable power generation technologies," Energy Economics, vol. 30, no. 4, pp. 18821908, 2008.

[40] Wood Mackenzie, “US solar market insight,” Wood Mackenzie, Edinburgh, 2018.

[41] D. Feldman, J. Hoskins, and R. Margolis, "Q4 2017/Q1 2018 solar industry update," National Renewable Energy Laboratory, Golden, 2018.

[42] Thailand's Load Forecast Sub-committee, .Thailand Load Forecast, version 26, January 2007. Bangkok: Energy Policy and Planning Office, 2007.

[43] C. Zhang, A. Romagnoli, J. Y. Kim, A. A. M. Azli, S. Rajoo, and A. Lindsay, "Implementation of industrial waste heat to power in Southeast Asia: An outlook from the perspective of market potentials, opportunities and success catalysts," Energy Policy, vol. 106, pp. 525-535, 2017. 